\title{
Web mapping application of Roman Catholic Church administration in the Czech lands in the early modern period
}

\author{
Pavel Seemann \\ Department of Geomatics, Czech Technical University in Prague, Czech Republic \\ pavel.seemann@fsv.cvut.cz
}

\begin{abstract}
Reconstruction of historical spatial relationships is still a topical issue in historical geography. In this respect, the Church history has not been well explored. The parish administration in the Czech lands is evolving since the advent of Christianity in 863, and a number of reforms have passed over the centuries. Significant changes in the administration also underwent during recatholisation of the Czech lands in the 17th and 18th century. From this Baroque era, there are written sources which have been preserved, so they can be utilized to reconstruct historical Church administration in the form of web mapping application. The paper briefly introduces methods which were used to build a spatial database filled with historical data. However, the main outcome of this paper is to describe the creation of the web mapping application that provides visualisation of this data. Discussed are topics like cartographic project, choice of map symbols, data generalization for different levels of detail and placement of annotations. Display of cartographic data were performed using the ArcGIS platform, through a combination of map tiles and feature services that are bundled into the application template created in Web AppBuilder.
\end{abstract}

Keywords: church administration; historical GIS; early modern period; web map; cartographic design.

\section{Introduction}

Nowadays, spatial data processing and creation of map outputs by applying geographic information systems (GIS) are conventional practice in many fields. Yet, there can be still found topics which has not been processed by this means. One of them was also a spatial reconstruction of the historical state of the Czech lands parish network in 1715. The need to devote time to Church administration in the 18th century became apparent during the preparation of the Academic Atlas of Czech History [23]. This topic was developed within the author's thesis [21]. The main outcome of the research is a web mapping application presenting collected data - in more detail discussed in the following text. Anyone interested can view application on website [5]. Moreover, the site contains other useful materials, such as texts about history of Church administration and religious communities in the Czech lands, specialized dictionary of religious terms, map application help, FAQs, downloads and so on. General public may use website to ease genealogical search for ancestors.

\section{Reconstruction of Historical Church Administration}

Church administration, as a spatial phenomenon, can be considered as an analogy to public administration (i.e. administrative divisions). But, instead of a state which is composed from counties, districts, municipalities and settlements at Church administration of early modern period, ecclesiastical provinces, archdioceses, vicariates/deaneries, parishes and settlements can be distinguished. For reference year 1715, which was chosen with regard to the available 
written sources, it was crucial to compile lists of settlements sorted by individual parishes, and reconstruct boundaries of these settlements, from which parishes and other Church units consists. Each Church administrative unit has also its main residence (seat of parson, vicar, bishop etc.).

The tasks of cooperating historians, especially Dr. Bobková-Valentová, were to study written sources with informations about historical Church administration and to prepare relevant data into a form suitable for GIS processing. The key sources for Bohemia were catalogues of benefices for Prague archdiocese and parish registers [1]. Thematic literature, younger catalogues of benefices 1734-1806 [24] and clerical questionnaires were also used.

There is no suitable cartographic work from the early 18th century depicting boundaries with proper precision for the Czech lands as a whole. So, the historical boundaries were obtained from younger cartographic sources. Current boundaries of cadastre units were chosen as the first approximation. These data were provided by Department of Geomatics CTU in Prague and they originate from Czech Office for Surveying, Mapping and Cadastre [25]. The current cadastre units were retroactively adjusted to the form in mid 19th century according to outline maps of the Stable cadastre units [26, 27]. Territorial districts obtained this way were further verified by Müller's map of Bohemia from 1720, First Military Survey from the years 1763-1783, Second Military Survey from the years 1836-1852 and some literature devoted to the history of settlement in the Czech lands $[12,16,17]$. This process led to the separation of settlements established between 1715 (reference year) and mid 19th century (time of Stable cadastre).

From the collected data, a spatial database of Church administration was compiled using ArcGIS software. Two basic classes of spatial data were created - the first one to store polygons of settlements, which make up parishes as the lowest level of Church administration, and the second one as a point class designed for residencies of Church authorities. Territories (i.e. polygons classes) of parishes, vicariates and dioceses were derived from the base polygon class by applying aggregation functions of GIS. Reference scale of spatial data precision was set at 1:200,000.

Nearly 6,000 settlements, covering about a third of the historical territory of Bohemia, have been processed yet. Parish network is fully compiled for Diocese of Litoměřice and partially for Prague archdiocese. Reconstruction for Diocese of Hradec Králové and Olomouc have not begun yet. The reason for this state is very difficult written data sources collection, which takes a lot of exploratory time.

As an example of similar study about historical boundaries of Czech lands, project [10] of Charles University in Prague, project [7] of Masaryk University in Brno or contributions [2, 4] can be mentioned. More information on the procedures used in compiling spatial database of Church administration can be found in the separate paper [22].

\section{Cartographic Project}

The extent and detail of the Church spatial database encouraged to present data in the form of an interactive map on the Internet [6]. Since the initial consideration of the topic, a web mapping application have been intended as the main output. Classic analogue map would be too restrictive for the issue. Online technologies are undergoing rapid development. They 


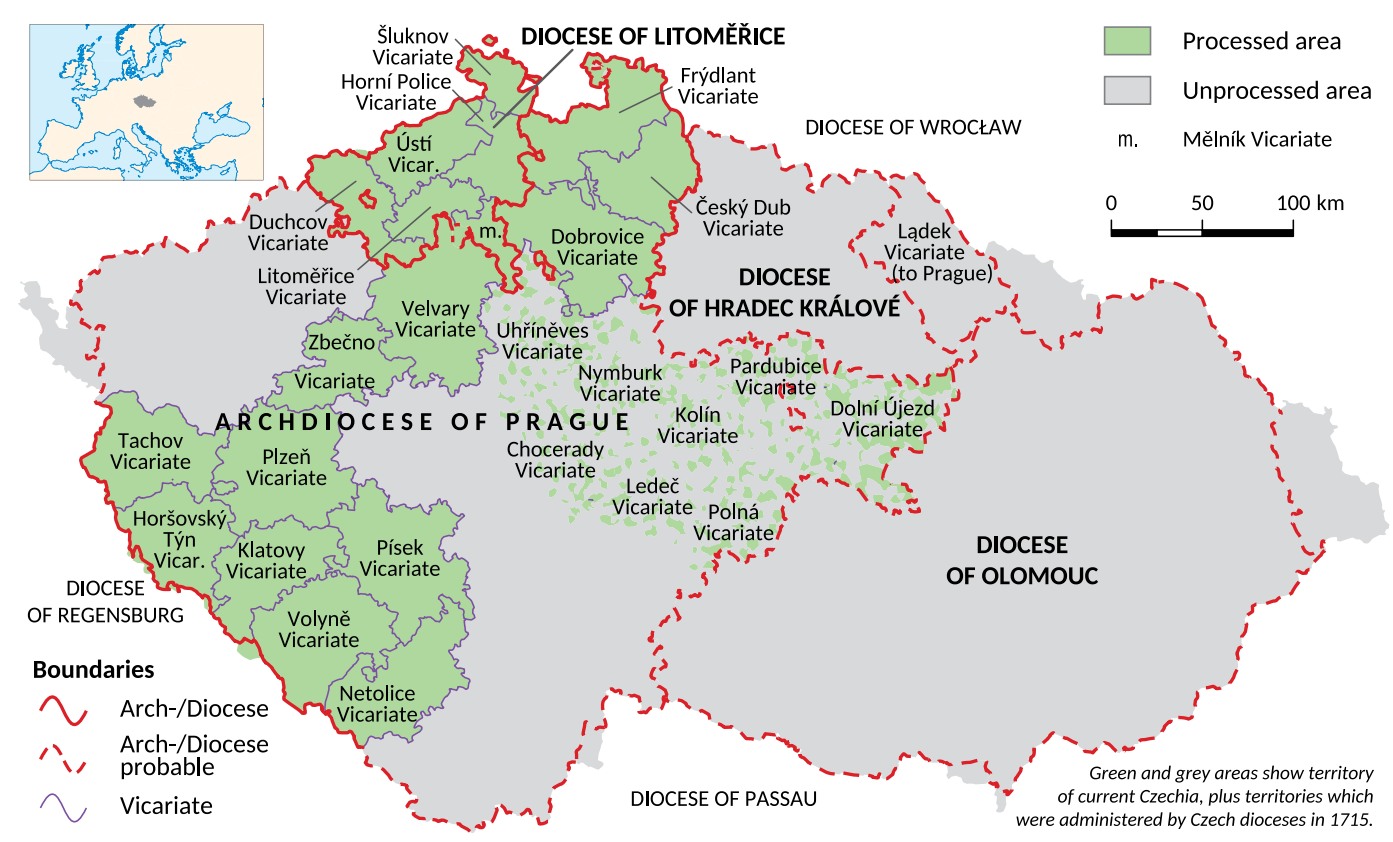

Figure 1: Current state of reconstruction of historical parish network in the Czech lands.

bring new perspectives and they can attractively represent spatial themes to the general public. So, at the beginning of elaboration, the following cartographic project according [28] was compiled.

Mapping application is targeting at professionals and trained laymen who have got a basic knowledge of Church administration in the early modern period. However, other user should be able to use map also after a minor study. Computer screen or tablet, from which the reader gains information by longer, not just a quick observation, was chosen as the output map medium. The platform ArcGIS, respectively ArcGIS Online, of the American company Esri was selected for the realization.

An advantage of internet data presentation is the ability to bind spatial data with different scales and related information detail into the one output. But for web maps, it is necessary to distinguish following types of scales - a reference scale of data, a reference scale of map layers and a reference scale of final map output. Last one is affected by chosen technology, medium and end-user screen resolution.

Reference scale for the data was determined by the source geodatabase and it is approximately 1:200,000. Reference scale of map layers (i.e. reference scale in ArcMap) affects size of point map symbols, line thickness and size of annotations. For web map, there is basically no difference whether to set reference scale larger and map symbols smaller, or smaller reference scale and larger map symbols. More important is to define map layers (levels, or in fact separate maps in classic point of view) and their contents.

Four map layers were designed as follows:

1. A small scale map showing dioceses of the Czech lands, which is drawn entirely on common widescreen monitor. 
2. A small scale map with vicariates and deaneries, which corresponds to a regional map.

3. A medium scale map where are captured territories of parishes, which matches with district map.

4. A large scale map presenting individual settlements.

The scale of map output (without considering pixel density of an output device) is related to chosen access technology for web maps. The Web Mercator map projection is today's de facto standard for Internet maps. This projection has got established scaling series denoted by the term Levels of Detail. Due to the facts that most of the mapping services are currently handled in this projection and that from a technological perspective it is very convenient when different map sources use the same cartographic projection, the Web Mercator was also chosen for web application of Church administration as a default projection. But only at levels 7-14 (scales 1:4,622,324 to 1:36,112), which roughly respect four proposed map layers described above.

The contents of all four thematic maps is consisting of administrative theme in the form of discrete qualitative area symbols, qualitative line symbols for ecclesiastical boundaries and qualitative point symbols representing residencies of Church authorities and later formed settlements. Topographical basemap is provided by a mashup of current and old maps, which are rendered via Web Map Services. The map key design was based on the theory of map language [15] and its creation is discussed in the articles [18, 20, 19].

For the preparation of map layers and cartographic processing, the program ArcMap was selected. This software works well with ArcGIS Online. Map application intended to an end user is based on a combination of raster data (map tiles) and interactive vector data. Application thin client interface design came out of ready-made templates.

\section{Data Generalization}

The requirement of four map outputs with different degree of detail necessarily led to the need for cartographic data generalization. Generalization is done either by simplifying map elements and phenomena, by choosing what to express or not, or by cartographic harmonization of map elements [11]. Two levels of detail in Web Mercator projection were associated with each of the four map layers - see Figure 2.

It have been found that the reference data scale 1:200,000 is satisfactory for the fourth and the most detailed map layer. However, data for the 3rd, 2nd and 1st map layer had to be generalized. Generalization of point features (Church residencies and later established settlements) was simple operation. It had been achieved by census choice of map elements, i.e. by a selection based on qualitative classification. As a census choice condition, the significance of settlement was selected. All point features have been preserved at levels 14 and 13. The layer of later established settlements is omitted at level 12. Centres of parishes and lower auxiliary offices are not displayed in the 11th and 10th level. And finally, levels 9-7 depicts only signs for seats of archdioceses and dioceses.

Polygon classes of settlements, parishes, vicariates and dioceses and line class of boundaries were generalized by combination of simplifying shapes and qualitative selection of map elements. The most detailed 4th map layer (levels 14 and 13) remained unchanged. The third 
map layer (levels 12 and 11) was generalized by census choice, so there are no longer displayed settlements boundaries.

For the second map layer, shapes of vicariates and boundaries were simplified. Boundary class was also diluted by census choice method. The generalization in ArcMap was achieved via Simplify Line tool with parameter Bend Simplify. Classes for the levels 10 and 9 were created by this tool and to these classes, reference data scale 1:750,000 was assigned.

The least comprehensive map layer (levels 8 and 7) was created in a similar way as the second. Shape simplification was achieved by Simplify Line tool using original data of dioceses boundaries. The entire generalization procedure is summarized in the Figure 2.

\begin{tabular}{|c|c|c|c|c|c|c|c|}
\hline \multirow[b]{2}{*}{$\begin{array}{l}\text { Map } \\
\text { Layer }\end{array}$} & \multirow[b]{2}{*}{$\begin{array}{l}\text { Reference } \\
\text { Data Scale } \\
\text { Number }\end{array}$} & \multirow[b]{2}{*}{$\begin{array}{l}\text { Reference } \\
\text { Scale } \\
\text { Number at } \\
\text { ArcMap }\end{array}$} & \multirow[b]{2}{*}{$\begin{array}{l}\text { Web } \\
\text { Mercator } \\
\text { Level }\end{array}$} & \multirow[b]{2}{*}{$\begin{array}{l}\text { Scale } \\
\text { Number Web } \\
\text { Mercator }\end{array}$} & \multicolumn{3}{|c|}{ Cartographic Generalization } \\
\hline & & & & & $\begin{array}{l}\text { Display of } \\
\text { Church } \\
\text { Residencies }\end{array}$ & $\begin{array}{l}\text { Later } \\
\text { Established } \\
\text { Settlements }\end{array}$ & $\begin{array}{l}\text { Bend } \\
\text { Simplify } \\
\text { Value }\end{array}$ \\
\hline \multirow{2}{*}{$1^{\text {st }}$} & \multirow{2}{*}{$3,000,000$} & \multirow{2}{*}{$6,930,000$} & Level 7 & $4,622,324$ & \multirow{3}{*}{ Diocese level } & \multirow{6}{*}{ No } & \multirow{2}{*}{$4,000 \mathrm{~m}$} \\
\hline & & & Level 8 & $2,311,162$ & & & \\
\hline \multirow{2}{*}{$2^{\text {nd }}$} & \multirow{2}{*}{750,000} & \multirow{2}{*}{$1,730,000$} & Level 9 & $1,155,581$ & & & $1000 \mathrm{~m}$ \\
\hline & & & Level 10 & 577,790 & \multirow{2}{*}{$\begin{array}{l}\text { Diocese and } \\
\text { Middle levels }\end{array}$} & & $1,000 \mathrm{mi}$ \\
\hline \multirow{2}{*}{$3^{\text {rd }}$} & \multirow{2}{*}{200,000} & \multirow{2}{*}{430,000} & Level 11 & 288,895 & & & \\
\hline & & & Level 12 & 144,447 & \multirow{3}{*}{$\begin{array}{l}\text { Diocese, } \\
\text { Middle and } \\
\text { Parish level } \\
\text { (all levels) }\end{array}$} & & \\
\hline \multirow{2}{*}{$4^{\text {th }}$} & \multirow{2}{*}{200,000} & \multirow{2}{*}{110,000} & Level 13 & 72,223 & & \multirow{2}{*}{ Yes } & \\
\hline & & & Level 14 & 36,112 & & & \\
\hline
\end{tabular}

Figure 2: Parameters of map layers and data generalization summary.

\section{Cartographic Visualisation}

Thematic layers have got their source in polygon, line and point classes of the Church administration geodatabase. For the web map, these layers were further processed to a combination of raster map tiles and vector feature services.

Point map signs for residencies of Church authorities were assigned according to the Church symbol container, described in the article [19]. Visual variable colour was used to emphasize higher map sign quality of archbishopric, bishopric, district vicarage in Bohemia and deanery in Moravia and Silesia. So, archbishopric and bishopric have got a red fill and signs for district vicarage and deanery have got an orange fill. Furthermore, map symbols were divided into two size groups respecting ecclesiastical structures. Clergy houses and lower auxiliary offices have got a slightly smaller signs than other residencies. Map symbols for residencies with only honourable meaning and for parish level use white fillings.

In the case that there was an overlap in Church functions, i.e. one clergyman held role of district vicar and also led its own parish (and could have the title of rector, dean, archdeacon, etc.), a composite map symbol was selected to illustrate this state. Solution in the form of doubling the sign at the data level (i.e. there would be two point features in the database) was not used, because each of the four map layers of the web application has got a different scale. There would be either collision of point map symbols (at small scale), or they would 
be too remote (at large scales). Moreover, interactivity for all point signs was intended. This condition excluded solution in the form of signs displacement provided by ArcMap cartographic representations, which would be reflected in the raster tiles layers.

Simple circle shape signs were set up for the point class storing later founded settlements. Their colour fill was derived from the century of settlement establishment.

Absence of water features in the thematic map substantially simplified representation of ecclesiastical boundaries. According to quality, three colours and three line thickness belongs to the three boundary levels which are diocesan, vicariant and parochial. Visual parameter structure is then utilized to distinguish already reconstructed boundaries and probable boundaries that are not entirely clear yet.

\section{Church Residencies}

1) Diocese level

ff Archbishopric

Bishopric

2) Middle level District vicarages located in Bohemia at:

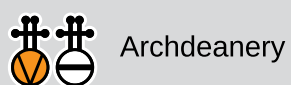

\#政 Deanery

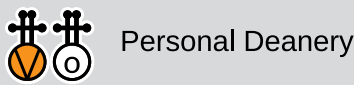

\#保 Archdiaconate

苦十 Clergy House, Rectory

Others on unprocessed territory

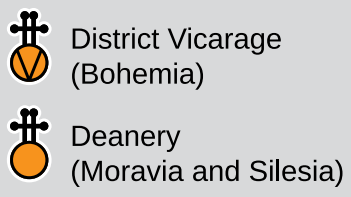

Settlements established after 1715

3) Parish level<smiles>[GeH][Te]</smiles>

(0) Personal Deanery

Archdiaconate

\pm Clergy House,

- Rectory

+ Administered

Rectory

$\ddagger$ Filial Rectory

+ Administered

Filial Rectory

\pm Exposed Chaplaincy

or Residential

Chaplaincy
- In the $18^{\text {th }}$ century

- In the $19^{\text {th }}$ century

- In the $20^{\text {th }}$ century

Established after 1715 unknown date

\section{Boundaries}

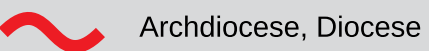

Archdiocese, Diocese (probable)

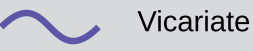

Vicariate

(probable)

Parish

Parish

(probable)

Settlement

Figure 3: The legend for Church administration of the Czech lands in 1715 used for the web map.

Qualitative areal signs were assigned to polygonal classes of dioceses, vicariates and parishes according to the conventions used for political and administrative maps. The four colour theorem (e.g. [14, p. 143]) shows that each planar political map might be coloured through four or more colours, so no two adjacent regions have got the same colour. In the case of two administrative levels (such as provinces and municipalities), several colour tones (named 
colours) are usually selected for a higher level. Changes in saturation of these colours are then used for a lower level. However, a minimum of $64\left(4^{3}\right)$ colours is required for three levels of Church administration. Given number faces the limits of the human eye to clearly distinguish so many colours within a single map. Therefore, four similar colour tones were selected for every diocese in the Czech lands: red-purple, green, blue, and brown-yellow. One of the four colours from diocesan group is allocated to vicariates (Bohemia) or deaneries (Moravia and Silesia). Five colour saturation is then used for parishes within single vicarage or deanery. Additional colours were chosen for the territories of Czechia, which fell in 1715 under foreign dioceses. To colour determination in the RGB model, the portal Sequential color schemes generator [3] helped a lot.

\begin{tabular}{|l|l|l|l|l|l|}
\hline & \multicolumn{5}{|c|}{ Colour code in the RGB model } \\
\hline \multirow{4}{*}{ Prague archdiocese } & $255,164,89$ & $255,186,129$ & $255,211,176$ & $255,231,212$ & $253,242,233$ \\
\cline { 2 - 6 } & $255,115,115$ & $255,148,144$ & $255,186,183$ & $255,217,216$ & $254,234,235$ \\
\cline { 2 - 6 } & $255,135,255$ & $255,165,255$ & $255,198,255$ & $255,224,255$ & $255,237,255$ \\
\cline { 2 - 6 } & $209,128,255$ & $222,158,255$ & $235,193,255$ & $245,223,255$ & $251,240,255$ \\
\hline \multirow{4}{*}{ Diocese of Litoměr̆ice } & $191,167,105$ & $206,185,137$ & $223,208,175$ & $238,229,210$ & $249,245,238$ \\
\cline { 2 - 6 } & $217,171,87$ & $229,189,125$ & $240,211,167$ & $247,229,204$ & $252,243,231$ \\
\cline { 2 - 6 } & $153,153,55$ & $175,172,95$ & $202,198,145$ & $227,223,194$ & $243,241,228$ \\
\cline { 2 - 6 } & $255,230,0$ & $255,238,118$ & $255,246,181$ & $255,252,223$ & $255,255,245$ \\
\hline \multirow{4}{*}{\begin{tabular}{l} 
Kiocese of Hradecé \\
\cline { 2 - 6 }
\end{tabular}} & $85,255,255$ & $154,255,255$ & $203,255,255$ & $231,255,255$ & $245,255,255$ \\
\cline { 2 - 6 } & $105,181,209$ & $144,195,216$ & $183,216,229$ & $219,235,242$ & $241,247,250$ \\
\cline { 2 - 6 } & $107,188,255$ & $152,204,255$ & $191,222,255$ & $223,238,255$ & $246,250,255$ \\
\cline { 2 - 6 } & $128,128,255$ & $160,153,255$ & $195,186,255$ & $224,218,255$ & $240,236,255$ \\
\hline \multirow{3}{*}{ Diocese of Olomouc } & $210,230,0$ & $230,238,113$ & $243,245,172$ & $250,250,213$ & $253,253,237$ \\
\cline { 2 - 6 } & $191,191,0$ & $213,207,95$ & $231,224,154$ & $243,238,199$ & $250,247,229$ \\
\cline { 2 - 6 } & $145,255,94$ & $183,255,144$ & $211,255,185$ & $230,255,214$ & $241,255,232$ \\
\cline { 2 - 6 } & $116,242,150$ & $164,247,181$ & $201,251,209$ & $225,253,229$ & $239,254,241$ \\
\hline Diocese of Regensburg & $161,196,137$ & $182,209,162$ & $208,226,196$ & $231,240,224$ & $244,248,240$ \\
\hline Diocese of Meissen & $102,179,179$ & $133,193,193$ & $173,213,212$ & $208,231,230$ & $231,243,243$ \\
\hline Diocese of Passau & $230,230,0$ & $242,237,105$ & $251,244,167$ & $254,249,209$ & $255,252,231$ \\
\hline Diocese of Wrocław & $214,157,188$ & $223,176,201$ & $234,202,219$ & $244,226,235$ & $250,242,246$ \\
\hline No Data & $225,225,225$ & & & & \\
\hline
\end{tabular}

Figure 4: Colours for areal symbols of parishes.

\section{Annotations}

It was also important to place annotations in all map layers. As indicated above, the web mapping application of Church administration consists of map tiles and feature services. The second said imaging method is used to represent point classes. Therefore, annotations for Church residencies and later established settlements are generated dynamically - they vary depending on displayed map scale. Annotations are firmly placed next to point map signs to which they belong. They occupy second or third hour position on an imaginary clock.

Conversely, areal annotations are carried out using prepared annotation classes in ArcMap, which are reflected in the map tiles. Computer font Corbel was selected for annotation classes. 
Mainly because this font has got good readability on computer screen [13, p. 55]. There is added asterisk at some settlement annotations at the 4 th map layer. This alerts map reader that supplementary note is registered for the locality.

Fixed annotation placing for areas was held in an iterative manner. So, none of them collide with dynamic annotation of point classes. This applies to every level of detail.

\section{The Layer Existence of Settlements in $\mathbf{1 7 2 0}$}

A thematic layer showing the existence of settlements in the Müller's map of Bohemia was also prepared for levels 14-11. It is based on auxiliary attribute registered in the polygon class representing settlements and uses some results of previous research with vector model of Müller's maps [9, 8]. The settlements displayed in the old Müller's map are represented by a green area map symbol in the new thematic layer. The settlements, which are not in the Müller's map, but known from written sources, have got a blue colour. Finally, the settlements, which were not proved younger or older origins, are marked in red colour. The current names of settlements together with names from Müller's map are used as annotations of this thematic layer - see Figure 5. The purpose of the entire map layer is to give readers additional information about the historical settlements situation. Red localities indicate an uncertainty in the existence of settlements. And so there is uncertainty about Church administration as well.

\section{Maps in ArcGIS Online}

ArcGIS Online technology offers a relative easy way to share spatial data on the Internet. It is enough to just have got an account to service and be able to control simple tools. Physical data storage and sharing technologies ensures cloud solution of ArcGIS Online. So, there is no need of having own hardware and software for map server.

The entire ArcGIS platform is constantly evolving and it is subject of improvements and changes. The current state what ArcGIS Online can do is good to draw directly from product pages $^{1}$, respectively from Help ${ }^{2}$. It is important for the web mapping application of Church administration that data and map compositions from the fat client ArcMap can be easily transferred into ArcGIS Online. This process consists of the following steps.

1. Offline data (maps) preparation in the form of

- Polygon, line and point classes for sharing through interactive (vector) feature services

- Map tiles

2. Uploading data to ArcGIS Online and their publishing that allows further work with data and their sharing

3. Creating a web map, which consists of map layers (feature services, map tiles, external Web Map Services), i.e. creating a map mashup. This step involves also choosing a map

\footnotetext{
${ }^{1}$ http://www .arcgis.com/home/

${ }^{2}$ http://doc.arcgis.com/en/arcgis-online/
} 


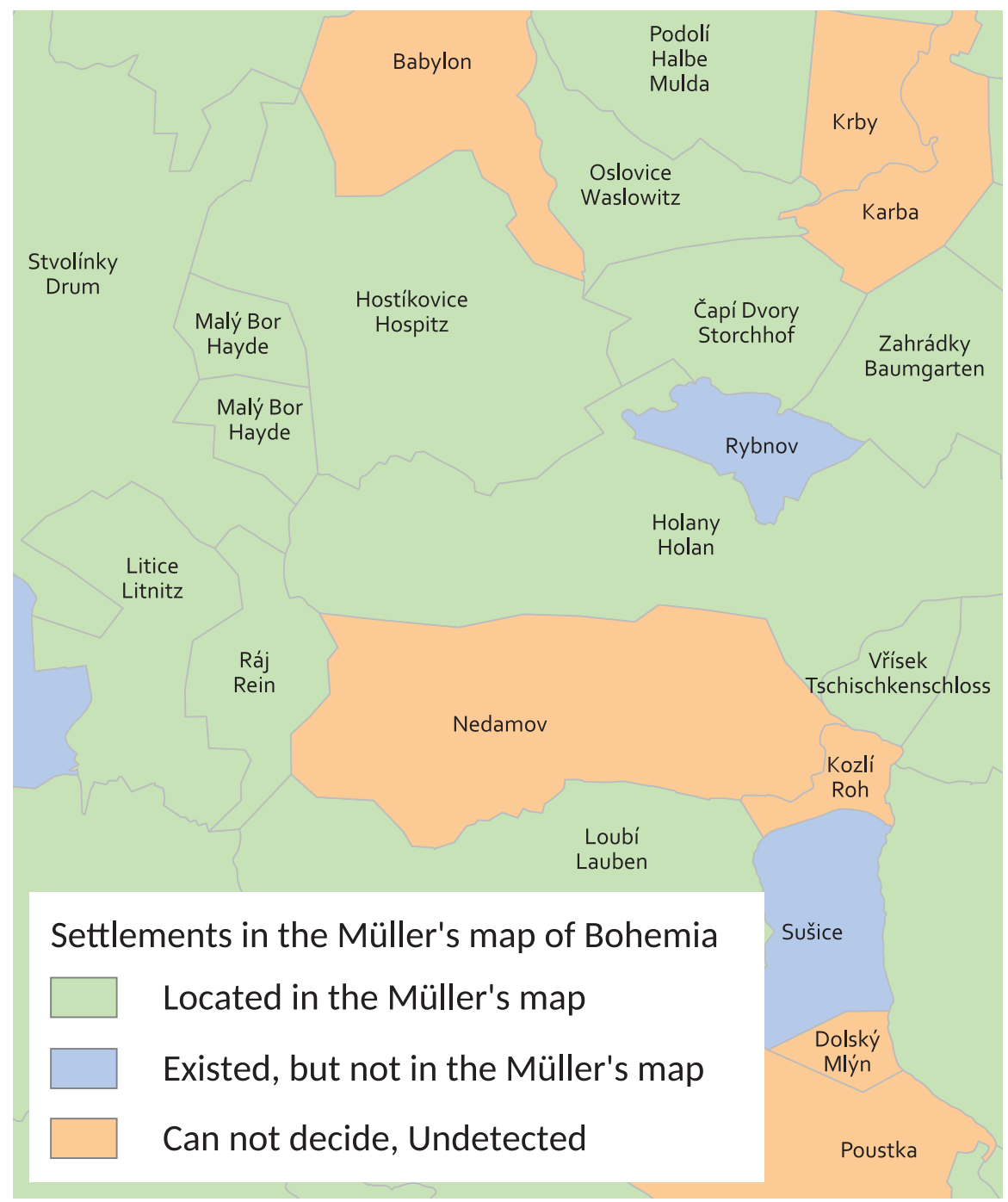

Figure 5: Detail of the auxiliary layer of the web mapping application which shows settlements represented in the Müller's map of Bohemia.

key for feature services, setting pop-up windows, scale intervals for layers visibility, etc. (See below)

4. Wrapping the web map into a web mapping application, which is an end-user interface containing map layers and additional tools for operating the map (such as search, scale bar, list of layers, legend, etc.)

5. Filling meta data and setting application sharing, possibly launching application on own web server

\section{Map Tiles}

The first step has been almost entirely described in the section Cartographic Visualisation. It remains only to clarify the process leading to creation of map tiles. Each of the map layers was 
prepared in a separate MXD file. This is true for the thematic layer existence of settlements in the Müller's map as well. In these map compositions, it was important to set correct transformation from S-JTSK system, in which the source data are stored, to Web Mercator projection (S_JTSK_To_WGS_1984_1). The reason was the right localization of map tiles. The production of tiles was then conducted by reusing tool Manage Tile Cache on to individual MXD files. The area where the tiles were generated was limited by auxiliary rectangle, which bounds Czechia. Other settings states Figure 6.

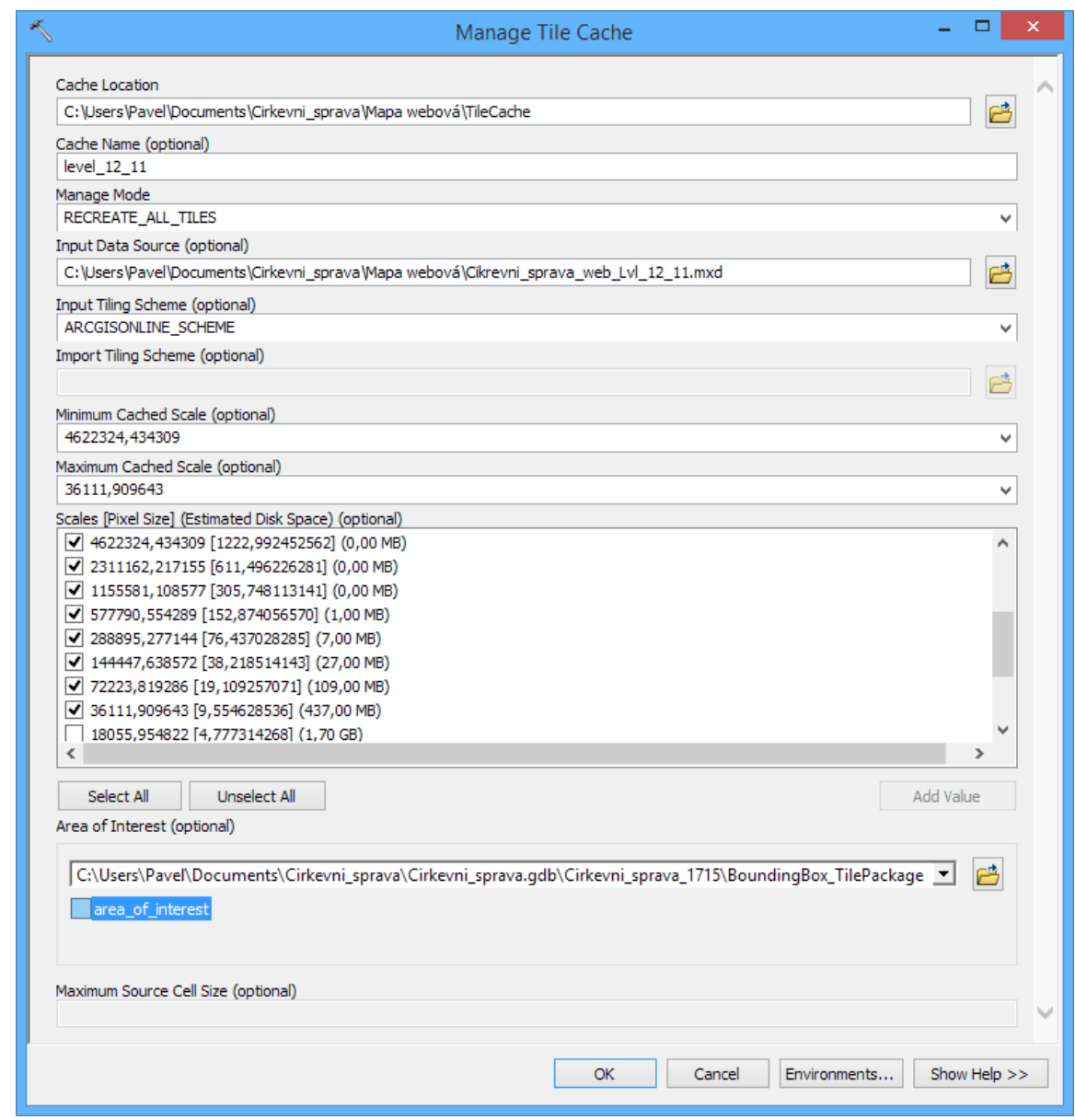

Figure 6: Manage Tile Cache tool settings which generates map tiles.

Subsequently, the four sets of map tiles were merged into one set using tool Import Tile Cache. Tile package file (TPK), suitable for sharing on ArcGIS Online, came from the tool Export Tile Cache. Map tiles generating was performed repeatedly with respect to various bugs fixes and general enhancements of map layers.

\section{Feature Services}

For feature services, a derived subsidiary file geodatabase became the data source. This geodatabase consists of the three point classes for residencies of Church authorities (diocesan, middle and parochial level), the point class for later established settlements and the polygon class for settlements territories. All classes contain only attribute columns that are necessary 
for the web map, or better said to the end user. So, auxiliary working attributes are omitted. Initially, it was planned to use shapefile for feature services, but this file format is limited by the maximum length of text string, which is 245 ASCII characters. This would not be enough for some notes that exceed this value.

\section{Web Map}

After data upload to ArcGIS Online, the web map assembly step followed. The Base Map of the Czech Republic was chosen as a basemap layer. This set of maps is provided by Czech Office for Surveying, Mapping and Cadastre in form of Web Map Service ${ }^{3}$. The main task of the basemap is to support orientation within Czechia. The basemap also replaces missing topography in the thematic map layers.

Raster equivalents of map signs in PNG were assigned to point feature services. Furthermore, the census choice method was applied by setting visibility of point map sings according to web map scale. The appearance of pop-up window was also configured.

Map tiles with territories of settlements, parishes, vicariates and dioceses were added as a layer named Church Administration in 1715 (Církevní správa v roce 1715). Unfortunately, raster tile layers in ArcGIS Online are restricted in functionality. They can not be searched, nor their attribute table can be viewed. Such informations are lost by conversion to raster form, and thus these informations have to be derived and supplied from the original vector data again. So, a polygon class of settlements territories (and their attributes) was also published within the subsidiary file geodatabase. The polygon class was simplified via Simplify Polygon tool (Bend Simplify, $100 \mathrm{~m}$ ) in order to reduce computing claims of the web mapping application.

Currently, ArcGIS Online allows to connect a supporting polygon class towards raster tile layer for the purpose of making pop-ups and geographic search. So, even a raster tile layer can be arranged to be interactive. However, it is not yet possible for the end user to access the attribute table of supporting polygon class. This fact limited planed functionality of the web map. But, it was bypassed by lowering simplicity and rationality in control of the final application. Therefore, there is added layer called Table of Church Administration in 1715 (Tabulka církevní správy $v$ roce 1715 ) over the tile layer. This is the described polygon class of settlements areas, which are not represented by any map sing and they are not visible in the map window. However, the user has got an option to access the attribute table. At the same time, this layer is set to geographic search and also serves as a data source for pop-ups.

Here are some of the tips that would benefit ArcGIS Online in the future - support of access to the attribute table of auxiliary vector layer connected to raster tile layer; the possibility of bringing multiple layers into one, where details would remain hidden for end user; or the ability to view only designer-selected layers at web map, i.e. there would be all layers in the map window but service layers would be hidden in the list of layers, so they would not confuse the user.

Several other inactive map layers that users can turn on to their needs have been added to the

${ }^{3}$ http://ags.cuzk.cz/arcgis/rest/services/zmwm/MapServer 
composition - Müller's map of Bohemia ${ }^{4}$, First Military Survey ${ }^{5}$, Second Military Survey ${ }^{6}$, the layer existence of settlements in the Müller's map and topographic map of the world by Esri. All these layers are designed to promote the acquisition of historical knowledge using maps confrontation.

\section{Web Mapping Application}

In the next stage, the layout of map layers, i.e. the web map, was encapsulated into a web mapping application. ArcGIS Online provides two ways how to do it. Map maker can either choose an application template or build the application via frequently-used function blocks called widgets in Web AppBuilder. The second method offers greater control over the appearance, settings and functionality of a web mapping application, so it was chosen for Church administration.

There are several ready-to-use visual and compositional themes in Web AppBuilder. After some experimenting, style named Foldable Theme was selected which has showed as the most appropriate for the application of Church administration. Following widgets were selected from offered functional blocks: Layer List, Attribute Table, Print, Search, Zoom Slider, Measurement, Home, Scalebar, Coordinate and Overview Map.

Comparison of contents of the each map layer is provided by several methods in the application of Church administration. First method is to switch on/off layers in the list of layers. Another way is to control their transparency in the same panel and last one is use Swipe tool. Basic informations about the entire web mapping application are summarized in the widget About, which is also used for the Help and Legend panels. Web AppBuilder offers special widget Legend for the list of map symbols, but it is not utilized because it fails to fully grant cartographic principles of legend composition. It also displays map signs explanation only for feature services, but not for map tiles. However, there is a drawback in using widget About instead of widget Legend. Legend widget has got a helpful property which is the scale dependency of visible map signs.

As the last step of the web mapping application preparation, sharing to everyone was set up to all necessary elements. Also, meta data was filled and the entire application was uploaded and put into operation in the portal Church Maps [5].

The application have been designed for non-GIS users. Therefore, download of raw spatial data is not implemented in the application itself. But anyone familiar with ArcGIS can find data through search tool at ArcGIS Online site. Or data can be asked via portal Church Maps also.

Comments of first users, i.e. historians and cartographers, has proved as a very valuable. Their inputs led to modification of map data, to improve functionality and clarity of the application as well as for writing help and FAQ for the application, which are published on the website. The resulting state after modifications is described in the preceding paragraphs.

\footnotetext{
${ }^{4}$ http://gis.fsv.cvut.cz/arcgis/rest/services/Muller_maps/Muller_Cechy_r/MapServer

${ }^{5}$ http://gis.fsv.cvut.cz/arcgis/rest/services/1vm/1vm/MapServer

${ }^{6}$ http://geoportal.gov.cz/arcgis/rest/services/CENIA/cenia_rt_II_vojenske_mapovani/MapServer
} 


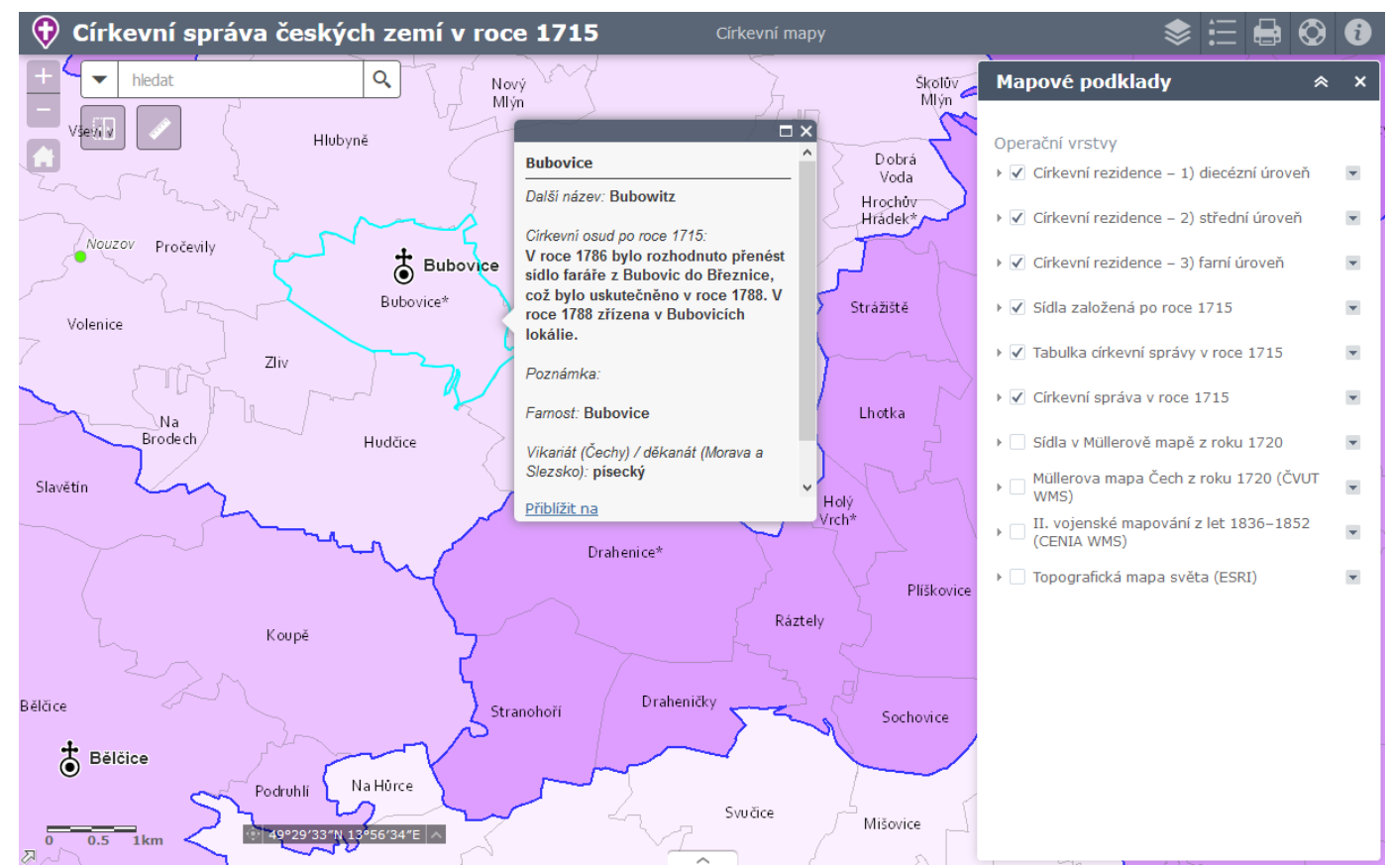

Figure 7: Web mapping application environment with pop-up window describing attributes about settlement Bubovice. At the upper left corner, there are base tools for scale change and search. Other controllers are at right corner, such as opened window for map layers.

\section{Conclusion}

The research of Church administration in the early modern period can be continued. The first step may be to complete unprocessed localities of the Czech lands for the year 1715 . The second step could be to extend the data of another historical levels, due to which a time GIS would arise. The collected data also carry enormous potential in terms of evaluating spatial relationships. Proper analysis can bring new insights and lead to changes in historical paradigms.

Processing of ecclesiastical issues into web mapping application has made this theme available to the general public in an attractive and modern form. ArcGIS Online has proved to be a good option that quickly and user-friendly presents the collected spatial data. Despite the minor flaws of platform tools, it is pleasing that ArcGIS Online is still evolving and improving. If spatial data are prepared, creation of a robust web mapping application with variable set of tools is a matter of hours or a few days. But there is one pitfall. ArcGIS Online is a proprietary and commercial platform, so sustainability of applications depends on yearly subscription. More laborious but independent could be to develop web mapping application using non-commercial software (e.g. Leaflet) on own server. If there will be some tight academic budget in the future, which will cause unavailability of the presented application, the migration of data to another platform should be considered.

To build a great application, it is necessary to continually pay attention to the proven cartographic rules for map composition, data generalization, choice of map signs and ensure an appropriate amount of communicated informations. Cartographer should not be temped by 


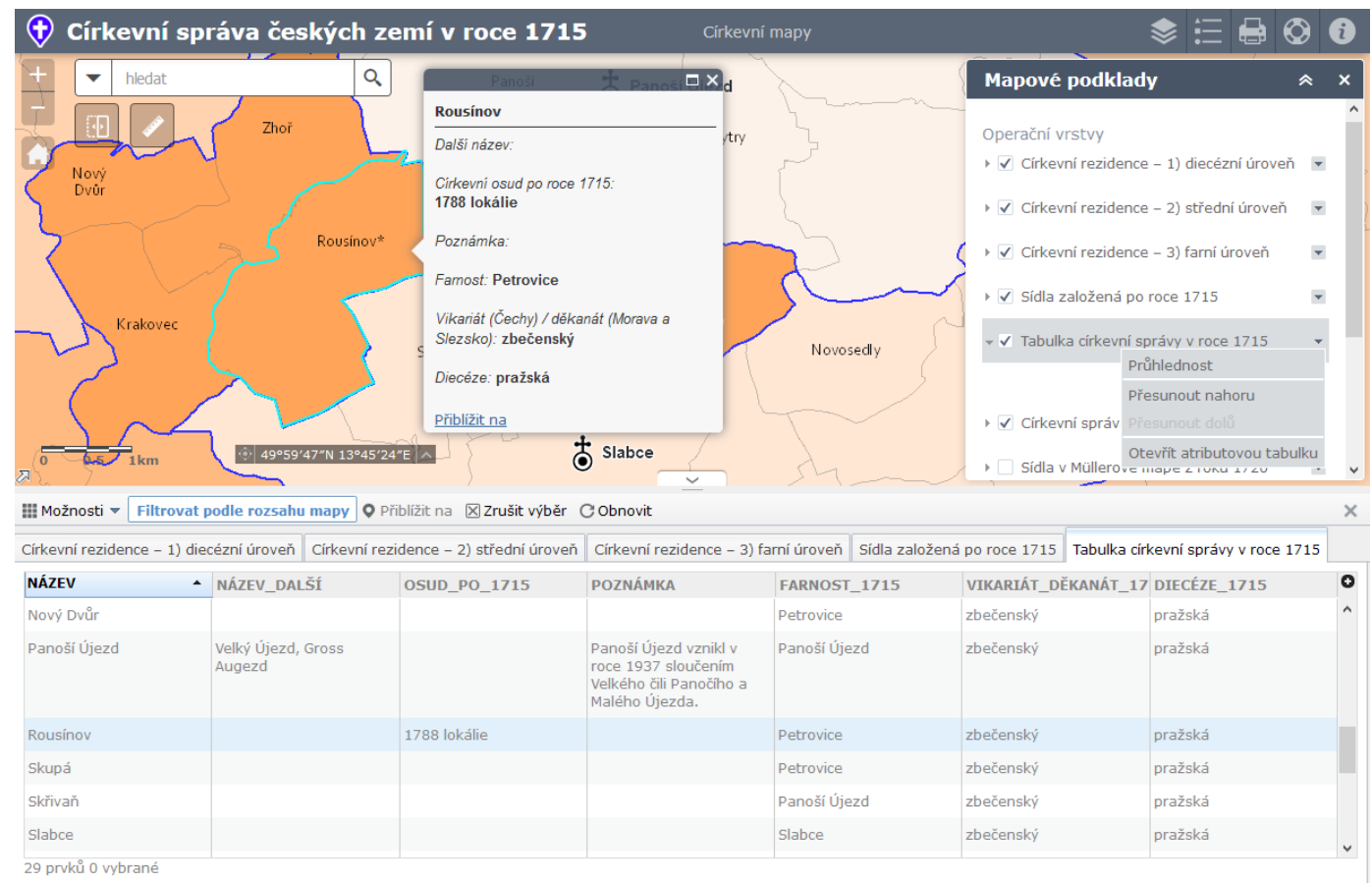

Figure 8: Another screen shot of web mapping application showing how to view attribute data - via pop-up window or via attribute table.

abundance of tools, widgets, templates, or predefined map symbols. Their choice should be conducted on the basis of careful thoughts on the purposes and aims of his or her work. It is worth to keep good design principles like "less is more" and "do not make me think". Important is also communication with developers of GIS software, thanks to which a cartographeruser can have an opportunity to influence cartographic tools and procedures within GIS software.

\section{References}

[1] Abecední seznam farář̃ a far. Národní archiv Praha, fond Archiv pražského arcibiskupství I, B 10/17, inv. č. 1305. 1715.

[2] Zdeněk Boháč. Atlas církevních dějin českých zemí 1918-1999. Karmelitánské nakladatelství, 1999. ISBN: 80-7192-405-9.

[3] Alžběta Brychtová and Jitka Doležalová. Sequential color schemes generator. http: //eyetracking.upol.cz/color/. cit. 2015-12-10. 2015.

[4] Tomáš Burda, Zbyněk Janoušek, and Pavel Chromý. "Historické hranice v prostř̌edí GIS: správní regiony v Česku 1920-2012". In: Historická geografie 40 (2014), pp. 41-72.

[5] Církevní mapy. Historické mapy českých zemí. uRL: http://www. cirkevnimapy.cz/.

[6] Radek Dostál and Vít Voženílek. "Interaktivita v kartografii". In: Geodetický a kartografický obzor 57/99, n. 5 (2011), pp. 107-113.

[7] Geografický informačni systém tradiční lidové kultury. URL: http://gistralik.muni. $\mathrm{cz} /$. 
[8] Jakub Havlíček. Analýzy nad vektorovými modely Müllerových map. Czech Technical University in Prague, Diplomová práce (master's thesis). 2011.

[9] Jakub Havlíček. Vektorový datový model Müllerovy mapy Čech. Czech Technical University in Prague, Bakalářská práce (bachelor's thesis). 2009.

[10] Historická data v GIS. URL: http://www.historickygis.cz/.

[11] Vladislav Hojovec et al. Kartografie. Geodetický a kartografický podnik v Praze, 1987.

[12] Josef Křivka. Nové osady vzniklé na území Čech v letech 1654-1854. Ústav československých a světových dějin ČSAV, 1978.

[13] Gretchen N. Peterson. Cartographer's Toolkit: Colors, Typography, Patterns. Fort Collins, Colorado, 2012. ISBN: 978-0-615-46794-8.

[14] Gretchen N. Peterson. GIS cartography: a guide to effective map design. 2nd edition. Boca Raton: CRC Press, 2014. ISBN: 978-1482220674.

[15] Ján Pravda. Mapový jazyk. 2nd edition. Univerzita Komenského, 2003. ISBN: 8022318094.

[16] Jiřina Růžková, Josef Škrabal, et al. Historický lexikon obcí České republiky 1869-2005. 1st edition. Vol. 1. Český statistický úřad, 2006. ISBN: 80-250-1310-3.

[17] Jiřina Růžková, Josef Škrabal, et al. Historický lexikon obcí České republiky 1869-2005. 1st edition. Vol. 2. Český statistický úřad, 2006. ISBN: 80-250-1311-1.

[18] Pavel Seemann. "Cartographic visualization of boundaries in Academic atlas of the Czech history". In: 14th International Multidisciplinary Scientific Geoconference SGEM 2014. Vol. III. Sofia, Bulgaria: STEF92 Technology Ltd., 1 "Andrey Lyapchev" Blvd., 2014, pp. 505-512. ISBN: 978-619-7105-12-4. DOI: 10.5593/SGEM2014/B23/S11.064.

[19] Pavel Seemann. "Církevní znaky pro historické mapy". In: ArcRevue 4/24 (2015), pp. 1416.

[20] Pavel Seemann. "Design map symbols for catholic religious institutes in the Czech lands". In: 15th International Multidisciplinary Scientific Geoconference SGEM 2015. Vol. II. Sofia, Bulgaria: STEF92 Technology Ltd., 51 "Alexander Malinov" Blvd., 2015, pp. 811-818. ISBN: 978-619-7105-35-3. DOI: 10.5593/SGEM2015/B22/S11.102.

[21] Pavel Seemann. "Geografický informační systém církevní správy v českých zemích v raném novověku". PhD thesis. Czech Technical University in Prague, 2016.

[22] Pavel Seemann. "Prostorová rekonstrukce církevní správy Čech v roce 1715". In: Folia Historica Bohemica 31/2 (2016), pp. 266-278.

[23] Eva Semotanová, Jiří Cajthaml, et al. Akademický atlas českých dějin. 1st edition. Academia, 2014, p. 559. ISBN: 978-80-200-2182-3.

[24] Seznam far a farářo podle vikariátu. Národní archiv Praha, fond Archiv pražského arcibiskupství I, B 10/18, inv. č. 1306, původní titulní list nedochován. 1734-1806.

[25] Soubor správních hranic a hranic katastrálních území ČR (File of Administrative Boundaries and Cadastral Units Boundaries of the CR). Geoportál ČUZK. http://geoportal. cuzk.cz/.

[26] Überssichts Karte der Steuer Bezirke und Katastral Gemeinden von Mähren und Schlesien. Ústřední archiv zeměměřictví a katastru. 12 map sheets, 1:115,200. 1839. 
[27] Uibersichts Karte aller Katastral Gemeinden in der Provinz Böhmen. Ústřední archiv zeměměřictví a katastru. 14 map sheets, 1:144,000. 1846.

[28] Vít Voženílek, Jaromír Kaňok, et al. Metody tematické kartografie: vizualizace prostorových jevi. Univerzita Palackého v Olomouci pro katedru geoinformatiky, 2011. ISBN: 978-80-244-2790-4. 